\title{
KEDUDUKAN SUAMI-ISTRI (KAJIAN SURAH AN-NISA' [4]: 34)
}

Oleh : Rahmawati Hunawa

Institut Agama Islam Negeri (IAIN) Manado

rahmahunawa@yahoo.com

\begin{abstract}
This paper examined the position of husband and wife in according to Islam. Qs. an-Nisa '[4]: 34 becomes the focus of the reference and analysis on this topic. Qs Study. an-Nisa [4]: 34 highlights a lot about women. This Surah became the liberator of women from the injustice of society towards women since 15 centuries ago. In marriage, husbands are obliged to lead and protect their wives and all family needs, while women on the male side are like body organs on a body, men as heads, and women as bodies. Qs. an-Nisa '[4]: 34 explains the position of men is higher than women, this is intended to reinforce the division of tasks between men as husbands and women as wives. The mention of the words ar-Rijal and an-Nisa in this verse does not emphasize biological significance, but rather character leadership and social functions. The figure of leadership (qawwam) is generally more dominantly indicated by men than women. The virtue of men in this verse is related to his responsibilities as head of the household. However, al-fadhl (excess) possessed by men does not make men (husbands) doing arbitrarily on their women (wives).
\end{abstract}

Keywords : Al-Rijal, An-Nisa', Qawwamun

Abstrak. Paper ini mengkaji tentang kedudukan suami dan istri dalam Islam. Qs. anNisa' [4]: 34 menjadi fokus acuan dan analisis tentang topik ini. Kajian Qs. an-Nisa [4]: 34 ini banyak menyoroti tentang perempuan. Surah ini menjadi pembebas perempuan dari ketidakadilan masyarakat terhadap perempuan sejak 15 abad silam. Dalam pernikahan, suami wajib memimpin dan melindungi isteri serta segala keperluan keluarga, sedangkan wanita di sisi kaum pria adalah laksana organ tubuh dalam raga yang satu, kaum pria sebagai kepala, sedangkan wanita sebagai badannya. Qs. an-Nisa' [4]: 34 menjelaskan kedudukan laki-laki lebih tinggi dari perempuan, hal ini dimaksudkan untuk mempertegas pembagian tugas antara lakilaki sebagai suami dan perempuan selaku isteri. Penyebutan kata ar-Rijal dan anNisa' dalam ayat ini tidak menekankan pada signifikansi biologis, tetapi lebih kepada kepemimpinan karakter dan fungsi sosial. Sosok kepemimpinan (qawwam) umumnya lebih dominan ditunjukkan oleh kaum laki-laki daripada perempuan. Keutamaan laki-laki dalam ayat ini dihubungkan dengan tanggung jawab nya sebagai kepala rumah tangga. Namun, al-fadhl (kelebihan) yang dimiliki oleh lakilaki lantas tidak menjadikan laki-laki (suami) berbuat semena-mena terhadap perempuan (isteri) nya.

Kata Kunci : Al-Rijal, An-Nisa', Qawwamun 


\section{Pendahuluan}

Pandangan yang berkembang dalam masyarakat mengenai status dan peran perempuan masih terbagi ke dalam dua kelompok yang berseberangan. Di satu sisi, umumnya berpendapat bahwa perempuan harus di rumah, mengabdi kepada suami, dan hanya mempunyai peran domestik. Di sisi lain, berkembang pula anggapan bahwa perempuan harus bebas sesuai dengan haknya tentang kebebasan. Perbedaan pandangan tersebut sangat terkait dengan adanya perbedaan dalam memahami teks-teks Al-Qur'an yang berbicara tentang relasi wanita.

Pada prinsipnya, perempuan dalam Islam memiliki derajat yang sama dengan laki-laki. Bahkan kaum perempuan mendapat tempat yang istimewa, karena menjadi nama dari salah satu surah dalam al-Qur'an yakni surah an-Nisa' dan sekaligus menjadi fokus pembahasan dalam tulisan ini. Permasalahan yang dimunculkan dalam tulisan ini adalah Bagaimana kedudukan laki-laki dan perempuan dalam rumah tangga yang tercantum dalam Q.S. AnNisa'[4]: 34 dan penggalan ayat berikutnya mengenai macam-macam isteri, yakni isteri yang taat dan tidak taat (nusyuz).

Untuk menjawab beberapa pokok permasalahan di atas, penulis menggunakan pendekatan, di antaranya; pendekatan kebahasaan, kitab-kitab tafsir, hadis dan literaturliteratur yang terkait dengan judul pembahasan.

\section{B. Pembahasan}

1. Teks Ayat Qs. An-Nisa': 34

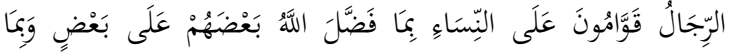

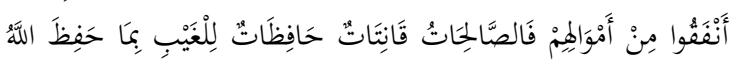

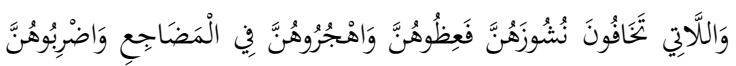

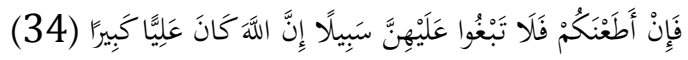

Artinya: Kaum laki-laki itu adalah pemimpin bagi kaum wanita, oleh karena
Allah telah melebihkan sebahagian mereka (laki-laki) atas sebahagian yang lain (wanita), dan karena mereka (lakilaki) telah menafkahkan sebagian dari harta mereka. sebab itu maka wanita yang saleh, ialah yang taat kepada Allah lagi memelihara diri ketika suaminya tidak ada, oleh karena Allah telah memelihara (mereka). wanita-wanita yang kamu khawatirkan nusyuznya, Maka nasehatilah mereka dan pisahkanlah mereka di tempat tidur mereka, dan pukullah mereka. Kemudian jika mereka mentaatimu, maka janganlah kamu mencari-cari jalan untuk menyusahkannya. Sesungguhnya Allah Maha Tinggi lagi Maha besar.

\section{-Kosa Kata}

$$
\begin{aligned}
& \text { = Pemimpin bagi } \\
& \text { قو امون علنتات = wanita taat } \\
& \text { تشوز = wanita pembangkang. }{ }^{1}
\end{aligned}
$$

\section{- Sabab an-Nuzûl Ayat}

Aspek sejarah suatu ayat al-Qur'an tidak bisa dilepaskan dari asbab annuzul. Asbab an-nuzul adalah peristiwa yang melatarbelakangi turunnya ayat alQur'an. Ayat ini diturunkan berkenaan dengan kasus yang dialami oleh Sa'id bin Rabi' yang telah menampar istrinya, Habibah binti Zaid bin Abi Hurairah, karena telah melakukan nusyûz (pembangkangan). Habibah sendiri kemudian datang kepada Rasul saw. dan mengadukan peristiwa tersebut yang oleh Rasul. Rasul kemudian memutuskan untuk menjatuhkan qishâs kepada Sa'id. Akan tetapi, Malaikat Jibril kemudian datang dan menyampaikan wahyu surat an-Nisa' ayat 34 ini. Rasulullah saw. pun lalu bersabda (yang artinya), "Aku menghendaki satu perkara, sementara Allah menghendaki perkara yang lain. Yang dikehendaki

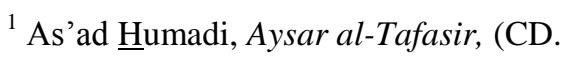
Maktabah al-Syamilah), hal.527
} 
Allah adalah lebih baik." Setelah itu, dicabutlah qishâs tersebut. ${ }^{2}$

Dalam riwayat yang lain, sebagaimana secara berturut-turut dituturkan oleh al-Farabi, 'Abd bin Hamid, Ibn Jarir, Ibn Mundzir, Ibn Abi Hatim, Ibn Murdawiyah, dan Jarir bin Jazim dari Hasan. Disebutkan bahwa seorang lelaki Anshar telah menampar istrinya. Istrinya kemudian datang kepada Rasul mengadukan permasalahannya. Rasul memutuskan qishâsh di antara keduanya. Akan tetapi kemudian, turunlah ayat berikut:

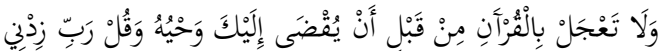

$$
\begin{aligned}
& \text { ع عِلْمًا .... }
\end{aligned}
$$

Janganlah kamu tergesa-gesa membaca al-Quran sebelum pewahyuannya disempurnakan kepadamu. (QS Thaha [20]: 114). Rasul pun diam. Setelah itu, turunlah surat an-Nisa' ayat 34 di atas hingga akhir ayat. ${ }^{3}$ Kisah yang sama juga dituturkan oleh Ibn Mardawiyah yang bersumber dari 'Ali. ${ }^{4}$

Semua peristiwa asbab an-nuzul tersebut merupakan gambaran konteks sosial masyarakat Arab ketika ayat ini diturunkan yang dibangun di atas sistem patriarkhi. Hal ini perlu dipahami karena konteks sosial saat itu berbeda dengan saat sekarang ini, sedangkan teks ayat masih sama. Untuk mendapatkan pemahaman yang mendalam terhadap suatu ayat, diperlukan kajian terhadap kondisi sosial bangsa Arab menjelang dan ketika ayat itu diturunkan. Dengan begitu, misi

2 Al-Wâhidi, Asbâb al-Nuzûl al-Qur'ân, (CD.Maktabah al-Syamilah), vol. I, hal. 100, baca pula: Wahbah al-Zuhaili, al-Fiqh al-Islamî wa Adillatuh (Beirût: Dâr al-Fikr, 1989), vol. V. h. 5354

${ }^{3}$ Abdur Rahmân ibn al-Kamâl Jalâluddîn asSuyûthi, Dâr al-Mansyûr fì at-Tafsîr al-Ma'tsûr, (Beirût: Dâr al-Fikr, t.th), vol. III, hal. 512-513.

${ }^{4}$ Jalâluddîn as-Suyûthi, Dâr al-Mansyûr fî at-Tafsîr al-Ma'tsûr, hal. 513.
al-Qur'an dari ayat ini dapat dipahami secara utuh. ${ }^{5}$

\section{Analisa Kebahasaan}

Ada tiga kata kunci yang perlu dibahas pada ayat di atas. Pertama, kata ar-rijal dan an-nisa'. Kata ar-rijal yang secara bahasa diterjemahkan lakilaki. Arti ar-rijal pada ayat ini jelas tertuju kepada 'kaum lelaki' karena berhadapan dengan kata an-nisa' yang berarti perempuan. Jelasnya, yang dimaksud dengan ar-rijal pada ayat tersebut adalah para suami.

Dalam terminologi al-Qur'an, kata ar-rijal diartikan laki-laki lawan perempuan dari jenis manusia. Kata ini umumnya digunakan untuk laki-laki yang sudah dewasa. ${ }^{6}$ Ar-rijal jamak dari kata ar-rajul dan an-nisa' dari al-mar'ah digunakan untuk menggambarkan kualitas moral dan budaya ssesorang. Berbeda dengan adz-dzakar dan aluntsa, penekanannya adalah jenis kelamin, yakni laki-laki dan perempuan. $^{7}$ Kata adz-dzakar juga digunakan untuk jenis kelamin binatang (Qs. al-An'am [6]: 144). Kata adz-dzakar dalam al-Qur'an mngacu kepada konteks kebahasaan dan dalam berbagai bentuknya terulang sebanyak 18 kali. ${ }^{8}$ Kata ini lebih banyak digunakan untuk menyatakan laki-laki dari faktor biologis (seks).

Dalam al-Qur'an kata ar-rajul memiliki kecenderungan variasi makna. Dalam surah al-Baqarah [2]: 282, kata

${ }^{5}$ Abdullah Saeed, Interpreting the Qur'an Towards a Contemporary Approach, (New York: Taylor \& Francis Group, 2006), hal. 116.

${ }^{6}$ Lihat Qs. al-Baqarah [2]: 282 : "Dan persaksikanlah dengan dua orang saksi dari lakilaki di antaramu"

${ }^{7}$ Lihat Qs. al-Hujurat [49]: 13 : “ Wahai sekalian manusia, sesungguhnya Kami telah menciptakan kamu dari seorang laki-laki dan perempuan, supaya kamu saling mengenal...."

${ }^{8}$ Muhammad Fuad Abdul Baqi, al-Mu'jam al-Mufahras li Alfazh al-Qur'an, (Beirut: Dar alFikr, t.th), hal. 275 
ar-rajul berarti gender laki-laki dan 55 kali disebut dalam al-Qur'an. ${ }^{9}$ Dalam Qs.al-Baqarah [2]: 282, menyebutkan kata ar-rijal berarti laki-laki tertentu yang mempunyai kapasitas tertentu, karena tidak semua laki-laki mempunyai tingkatan lebih tinggi daripada perempuan. Dalam Qs. anNisa' [4]:34, kata ar-rijal berarti pelindung (protector, maintainer) sesuai dengan sabab nuzul ayat ini. Keutamaan laki-laki dihubungkan dengan tanggung jawab nya sebagai kepala rumah tangga. ${ }^{10}$

Dalam kamus al-Muhith, seorang laki-laki dikatakan rajul jika dia telah melewati usia baligh, yakni setelah dia mimpi basah dan dapat dikatakan sebagai orang dewasa. Seorang dapat dikatakan sebagai rajul jika dia telah memiliki sifat rajuliah (kedewasaan). ${ }^{11}$ Pengertian kata ar-rajul dengan makna ini sejalan dengan kata qawwamun yang terletak setelah kata ar-rijal pada ayat ini yang berarti pemimpin, yang mana sifat kedewasaan merupakan salah satu syarat yang harus dimiliki oleh seorang pemimpin.

Kata an-nisa yang merupakan lawan dari ar-rijal juga disebutkan dalam Qs. an-Nisa' [4]: 34. Tentang pengertian an-nisa', kata ini adalah bentuk jamak dari kata niswah, bisa juga jamak dari al-mar'ah yang berarti perempuan yang sudah matang atau dewasa. ${ }^{12}$ Term yang lain untuk hal ini adalah kata al-untsa, yang bermakna

${ }^{9}$ Muhammad Fuad Abdul Baqi, al-Mu'jam al-Mufahras li Alfazh al-Qur'an, (Beirut: Dar alFikr, t.th), hal. 302-303

${ }^{10}$ Kementerian Agama RI, Tafsir Al-Qur'an Tematik, (Jakarta: PT Sinergi Pustaka Indonesia, 2012), hal. 14

${ }^{11}$ Muhammad bin Ya'qub Fayruzabady, alQomus al-Muhith, (Kairo: al-Haiah al-Mishriyah al- 'Ammah li al-Kitab, 1980), hal. 369

${ }^{12}$ Ibnu Manzur, Lisan al- 'Arab, (Beirut: Dar al-Kutub al-'Ilmiyyah, 2002, Ma'arif), Jilid XV, hal.321, bandingkan dengan Muhammad Fuad Abdul Baqi, al-Mu'jam al-Mufahras li Alfazh alQur'an, (Beirut: Dar al-Fikr, t.th), hal. 513 jenis kelamin perempuan secara umum, dari yang masih bayi sampai berusia lanjut. Kata an-nisa terulang sebanyak 59 kali dalam al-Qur'an. ${ }^{13}$

Kata niswah yang merupakan bentuk tunggal dari kata an-nisa' dapat diasalkan dari kata nasiya yang berarti lupa. Penisbatan kata nisa' dengan kata niswah menunjukkan kepada orang yang meninggalkan pekerjaan. ${ }^{14}$

Abdullah Yusuf Ali secara konsisten menerjemahkan ar-rajul dengan the man dan an-nisa'/al-mar'ah dengan the woman/the women. Sementara adz-dzakar diterjemahkan dengan the male dan al-untsa dengan the female. ${ }^{15}$

Selanjutnya dari struktur kalimat dalam ayat ini, kata ar-rijal dan an-nisa', keduanya berbentuk ma'rifah dengan tambahan alif lam yang dalam gramatikal bahasa Arab dikenal sebagai alif lam ma'rifah. Alif lam ma'rifah ini berfungsi menunjukkan bahwa kata tersebut sudah diketahui. Dengan demikian, dapat diketahui dari konteks turunnya ayat dan kandungan keseluruhan struktur kalimat bahwa arrijal merujuk kepada suami dan an-nisa' merujuk kepada istri. ${ }^{16}$ Pertanyaan yang kemudian muncul adalah mengapa dalam ayat tersebut menggunakan kata ar-rijal yang artinya kaum lelaki? Mengapa tidak menggunakan kata alazwaj yang artinya para suami? Bisa jadi kalau pemilihan kata ar-rijal dan annisa' dan tidak digunakannya $a d z-$ dzakar dan al-untsa ataupun az-zauj dan

\footnotetext{
${ }^{13}$ Muhammad Fuad Abdul Baqi, al-Mu'jam al-Mufahras li Alfazh al-Qur'an, (Beirut: Dar alFikr, t.th), hal. 699

${ }^{14}$ Ibnu Manzur, Lisan al- 'Arab, (Beirut: Dar al-Kutub al-'Ilmiyyah, 2002), Jilid XV, hal.415

${ }^{15}$ Kementerian Agama RI, Tafsir Al-Qur'an Tematik, (Jakarta: PT Sinergi Pustaka Indonesia, 2012), hal. 15

${ }^{16}$ Abdurrahman, dkk., Al-Qur'an dan Isu-isu Kontemporer, (Yogyakarta: eLSAQ Press, 2011), hal. 341
} 
az-zawjah merupakan salah satu rahasia pemilihan bahasa al-Qur'an yang menunjukkan keluasan makna yang terkandung di dalamnya. Atau barangkali ada pesan yang ingin alQur'an bahwa keluarga haruslah terdiri dari seorang laki-laki dan perempuan yang hidup bersama dalam satu ikatan pernikahan. Hal ini jelas bertentangan dengan budaya kaum 'gay' yang menginginkan agar keluarga bisa terdiri dari dua orang lelaki.

Kata ar-rijal digunakan dalam ruang lingkup keluarga untuk menegaskan bahwa pada dasarnya suami yang nota bene lelaki yang secara fisik lahiriah lebih kuat itu adalah mengayomi, mengurusi, melindungi, dan bertanggung jawab atas isterinya yang perempuan. Dengan demikian, lelaki lah yang pantas menjadi kepala keluarga dalam kehidupan rumah tangga.

Kedua, makna kata qawwamun. Kata ini merupakan bentuk jamak dan mubalaghah dari kata qa'im dalam bentuk isim fa'il yang mempunyai konotasi berdiri secara terus menerus. Jika dikatakan: fulan qama 'ala syay'in artinya si fulan adalah orang yang mengurus sesuatu. Adapun qayyim almar'ah adalah zawjuha atau suaminya, karena dia memiliki hak mengaturnya dan memenuhi kebutuhannya. ${ }^{17}$

Penggunan sighah mubalaghah (artinya sangat) atau bentuk yang paling tinggi/paling banyak dalam melakukan suatu pekerjaan, menunjukkan bahwa tugas seorang suami itu berat, karena dia betul-betul menjaga, mengawasi, mengayomi, mendidik,secara terus menerus. Allah swt adalah al-Qayyum artinya Dzat yang selalu menjaga makhluk-Nya secara terus menerus. ${ }^{18}$

\footnotetext{
${ }^{17}$ Ibnu Manzur, Lisan al- 'Arab, (Beirut: Dar al-Kutub al-'Ilmiyyah, 2002, Ma'arif), hal. 174

${ }^{18}$ Ahsin Sakho Muhammad, Keberkahan alQur'an; Memahami Tema-tema Penting dalam
}

Ibn al-'Arabi menafsirkan qawwam pada ayat ini dengan amin alaiha yang diartikan orang yang dipasrahi, yang menjaganya dan memberinya rasa aman, mengurusi segala kebutuhannya serta memperbaiki keadaannya. ${ }^{19}$ Ibn Katsir mengartikan kata qawwam pada ayat ini dengan pemimpin, pembesar, penguasa, dan pendidik yang senantiasa mengurusi dan membimbingnya. Dia juga menafsirkan kata qawwam dengan umara' (penguasa kota/daerah) yang harus ditaati selama dalam ketaatan kepada Allah. ${ }^{20}$ At-Thabari juga menafsirkan kata qawwam dengan ahlu qiyam yang diartikan sebagai penanggung jawab, yakni bertanggung jawab mengurusi isterinya, bertanggung jawab membimbingnya dan menanggung segala kebutuhannya. ${ }^{21} \mathrm{Al}-$ Razi juga menambahkan bahwa kepemimpinan suami atas isterinya mencakup kekuasaannya mengatur, membimbing, serta menjamin perlindungan dan keamanannya. ${ }^{22}$ Sedangkan menurut al-Alusi, kepemimpinan suami atas isterinya layaknya kepemimpinan para penguasa atas rakyatnya yang memiliki hak penuh untuk memerintah dan melarang. ${ }^{23}$

Penafsiran klasik di atas menunjukkan adanya dominasi kaum lelaki atas perempuan. Meskipun begitu, dari beberapa penfsiran klasik tersebut dapat disimpulkan bahwa kata qawwam

Terang Kitab Suci, (Jakarta: PT.Qaf Media Kraetiva, 2017), Cet. 1, hal. 246

${ }^{19}$ Ibn al-'Arabi, Ahkam al-Qur'an, (Beirut:

Dar al-Kitab al-'Ilmiyyah, t.th), hal. 530

${ }^{20}$ Ibn Katsir, Tafsir al-Qur'an al-'Adzim,

(Giza: Maktabah Aulad al-Syeikh li at-Turats, 2000), hal. 20

${ }^{21}$ Muhammad bin Jarir at-Thabari, Tafsir atThabari Jami' al-Bayan 'an Ta'wil Ayat al-Qur'an, (Kairo: Maktabah Ibnu Taimiyyah, t.th), hal. 290

${ }^{22}$ Muhammad al-Razi, Tafsir al-Fakhr arRazi, (t.tp: Dar al-Fikr, t.th), hal. 90-91

${ }^{23}$ Syihabuddin Sayyid Mahmud al-Alusi, Ruh al-Ma'ani fi Tafsir al-Qur'an al-Adzim wa asSab'u al-Matsani, (Beirut: Idarah al-Tiba'ah alMuniriyah, t.th), hal. 90-91 
menunjukkan kepada beberapa makna yang hampir berdekatan, yakni pemimpin, pelindung, pengayom, pembimbing, dan penguasa. Tetapi perlu dikemukakan disini ialah bahwa status suami sebagai qawwam atas isterinya buka berarti suami bisa saja memperlakukan isteri dengan semenamena. Jika hal itu terjadi, suami memperlakukan isteri dengan kekerasan, maka jelas bukan itu yang dimaksud dengan qawwam. Bahkan Nabi SAW telah menandaskan bahwa indikator kebaikan seseorang adalah kebaikannya kepada isterinya. ${ }^{24}$

Ketiga, kata al-fadhal yang bermakna kelebihan. Pada ayat ini Allah Swt menjelaskan keutamaan yang ada pada masing-masing suami isteri yang terdiri dari laki-laki dan perempuan. Allah tidak menyebutkan keutamaan pada masing-masing. Kalau dirunut pada ayat sebelumnya (ayat 32), Allah melarang masing-masing lelaki dan perempuan mempunyai iri hati terhadap apa yang menjadi kelebihan pada masing-masing. Tidak bisa dipungkiri bahwa masing-masing dari suami atau isteri mempunyai keutamaan yang tidak dimiliki oleh yang lain, baik materi, keuangan, jabatan, ilmu, dan sebagainya.

\section{Tafsir Ayat}

Melalui Qs. an-Nisa' [4]: 34 ini Allah Swt. mengingatkan kita bahwa terdapat sebab kelebihan seorang lakilaki atas seorang wanita, setelah pada ayat sebelumnya Allah swt menjelaskan bagian dari masing-masing (pria maupun wanita) dalam waris, dan melarang keduanya untuk menganganangankan kelebihan yang telah Allah tetapkan bagi sebagian mereka (kaum pria) atas sebagian yang lain (kaum wanita).

\footnotetext{
${ }^{24}$ Lihat Sunan at-Tirmidzi (no.3895); Ibn Majah (no. 1977).
}

Jika kita membuka tafsir-tafsir klasik kalangan ulama terkemuka pada masa lalu, mereka pada umumnya sepakat manakala membedah pengertian "ar-rijâlu qawwâmûna 'ala an-nisâ", bahwa laki-laki baik dalam konteks keluarga maupun bermasyarakat, memang ditakdirkan sebagai pemimpin bagi kaum wanita.

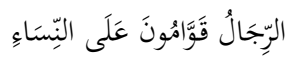

Frasa ar-Rijâl qawwâm 'alâ annisâ' bermakna bahwa kaum pria adalah pemimpin kaum wanita, yang lebih dituakan atasnya, yang menjadi pemutus atas segala perkaranya, dan yang berkewajiban mendidiknya jika melenceng atau melakukan kesalahan. Seorang pria berkewajiban untuk melakukan perlindungan dan pemeliharaan atas wanita. Oleh karena itu, jihad menjadi kewajiban atas pria dan tidak berlaku bagi wanita. Pria juga mendapatkan bagian waris yang lebih besar daripada wanita karena pria lah yang mendapatkan beban untuk menanggung nafkah atas wanita. ${ }^{25}$

Muhammad 'Ali Ash-Shabuni dalam Shofwah at-Tafasir ketika menafsirkan ayat ini menyatakan bahwa suami memiliki kewajiban terhadap isterinya untuk menjaga, mendidik, dan memberikan nafkah. Sementara isteri yang shalihah adalah yang tunduk dan patuh kepada Allah dan kepada suaminya, melaksanakan segala kewajibannya, menjaga dirinya dari perbuatan buruk, serta menjaga harta suaminya dari kemubaziran. Keduaduanya memiliki kewajban untuk saling menutupi, saling melengkapi kekurangan, dan menjaga rahasia pribadi masing-masing. ${ }^{26}$

Melalui kepemimpinan suamiisteri yang saling menjaga dan

${ }^{25}$ Wahbah al-Zuhaili, al-Fiqh al-Islami wa Adillatuh, hal. 54

${ }^{26}$ Ali Shâbuni, al-Shafwah al-Tafâsir, (Beirût: Dâr al-Fikr, t.th), vol. II, hal. 273 
memelihara disertai pembagian tugas yang komprehensif dan saling melengkapi, atas dasar cinta dan kasih sayang, diharapkan akan terbangun keluarga yang kokoh dan kuat, serta melahirkan keluarga yang sejahtera dan selamat di dunia maupun di akhirat (keluarga sakinah).

At-Thabari dalam tafsirnya menjelaskan ayat al-rijâl qawwûmûna 'alâ al-nisâ bahwa kepemimpinan lakilaki atas perempuan itu didasarkan atas refleksi kekuatan fisik pendidikan, dan kewajibannya untuk memenuhi seluruh kewajiban yang ditentukan oleh Allah. Hal ini pula yang menjadi sebab keutamaan laki-laki atas perempuan, seperti tercermin dalam kalimat $w a b i$ mâ anfaqû min amwâlihim yang ditafsirkan sebagai kewajiban untuk membayar mahar, nafkah, dan kifâyah. ${ }^{27}$

Keutamaan laki-laki ditinjau dari segi kekuatan akalnya serta kekuatan fisiknya, sehingga kenabian pun menjadi hak bagi kaum laki-laki. Dengan kekuatan akal dan fisiknya inilah, kepemimpinan dalam bentuk khalifah (al-imâmah al-kubrâ) dan al-imâmah alsugrâ, seperti imam salat, kewajiban jihad, azan, iktikaf, saksi, hudûd, qishash, perwalian dalam nikah, talak, rujuk, dan batasan jumlah istri, semuanya disandarkan kepada laki-laki. ${ }^{28}$

Selanjutnya ayat;

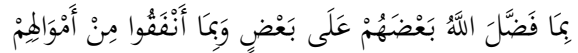

Pada frasa bimâ fadhdhala Allâh ba'dhahum 'alâ ba'dhin wa bima anfaqu min amwalihim, yang secara literal berarti "oleh karena Allah telah melebihkan sebgaian mereka (laki-laki) atas sebagian yang lain (perempuan),

${ }^{27}$ Abû Ja'far Muhammad bin Jarîr bin Yazîd al-Tabarî, Tafsîr al-Tabarî, Jilid IV, (Kairo: Bûlâq, $1323 \mathrm{H})$, h. 40

${ }^{28}$ Abû Ja'far Muhammad bin Jarîr bin Yazîd

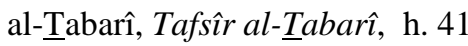

dan karena mereka (laki-laki) telah menafkahkan sebagian harta mereka".

Ungkapan tersebut terdiri dari dua

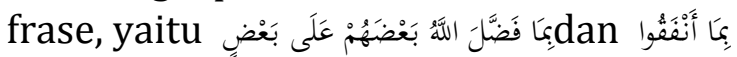

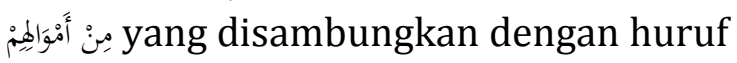
athof/ kata sambung waw (dan). Selanjutnya fungsi huruf $b a$ yang terdapat dalam kalimat di atas adalah $b a$ sababiyah yang berkaitan erat dengan kata qawwâmûn. Dengan begitu dapat dipahami, bahwa kepemimpinan kaum pria atas wanita adalah karena kelebihan yang telah Allah berikan kepada mereka (kaum pria) atas kaum wanita. ${ }^{29}$

Menurut al-Razi, kedua frase tersebut merupakan alasan kepemimpinan ar-rijal atas an-nisa'. AlRazi mengartikan frase yang kedua secara semantik merupakan bagian dari frase yang pertama. Frase yang kedua menerangkan frase yang pertama, karena makna yang terkandung di dalam frase kedua terdapat pada frase pertama yang merupakan salah satu unsur yang menyusun maknanya secara keseluruhan. Pada penafsiran ini harta yang diberikan suami kepada isterinya, baik berupa mahar maupun nafaqoh merupakan salah satu kelebihan yang dimiliki oleh laki-laki. ${ }^{30}$

Ibn Katsir dalam tafsirnya, menyatakan bahwa laki-laki adalah pemimpin, penguasa, kepala, dan guru pendidik bagi kaum wanita. Ini disebabkan karena berbagai kelebihan laki-laki itu sendiri atas wanita, sesuai dengan firman Allah: li ar-rijâl 'alaihinna darajah (bagi laki-laki ada kelebihan satu tingkat dari wanita) (QS al-Baqarah [2]: 228). Selain itu, karena laki-laki

29 Shihâbuddîn Mahmûd al-Alûsy, Rûh alMa 'ânî Fi Tafsîr al-Qur'ân al-Azhîm wa Sab'a alMatsâni, (Beirût: Dâr al-Fikr, ), vol. I, hal. 23

${ }^{30}$ Al-Razi, Tafsir Fakhr ar-Razi, hal. 91 
berkewajiban menafkahi istri dan anakanaknya. ${ }^{31}$

Dalam kurun yang amat panjang, dari mulai Ibn 'Abbas, at-Thabari, bahkan hingga Imam 'Ali ash-Shabuni, tafsir tersebut tidak banyak digugat, kecuali belakangan manakala pemikiran-pemikiran Islam mulai bersinggungan dengan wacana pemikiran Barat dan juga fakta yang memang menunjukkan tidak sejalannya lagi penafsiran tersebut dengan realitas kontemporer. Ibn 'Abbas, misalnya, mengartikan kata qawwâmûn sebagai pihak yang memiliki kekuasaan atau wewenang untuk mendidik wanita.

Senada dengan hal tersebut, atThabari menegaskan, bahwa kata qawwâmûn bermakna penanggung jawab, dalam arti, pria bertanggung jawab dalam mendidik dan membimbing wanita dalam konteks ketaatannya kepada Allah. ${ }^{32}$

Sementara itu, menurut Imam alQurthubi, pria adalah pemimpin wanita karena kelebihan mereka dalam hal memberikan mahar dan nafkah; karena pria diberi kelebihan akal dan pengaturan sehingga mereka berhak menjadi pemimpin atas wanita; juga karena pria memiliki kelebihan dalam hal kekuatan jiwa dan watak. Surah anNisa' ayat 34 ini juga menunjukkan kewajiban pria untuk mendidik wanita. ${ }^{33}$

Sedangkan Imam asy-Syaukani, ketika menafsirkan ayat di atas, menyatakan bahwa pria adalah pemimpin wanita yang harus

${ }^{31}$ Abû al-Fidâ' Ibn Katsîr, Tafsîr al-Qur'ân al-Azhîm, (Beirût: Dâr al-Fikr, 1401), vol. I, hal. 596

32 Abû Ja'fâr, Muhammad ibn Jarîr ibn Yazîd ibn Khâlîd ath-Thabâri, Jâmi' al-Bayân 'an Ta'wîl Ay al-Qur'ân, (Beirût: Dâr al-Fikr, 1405 H), vol. v hal. 48

${ }^{33}$ Abû Abdillah, Muhammad ibn Ahmad ibn Abi Bakr ibn Farah al-Qurthûbi, al-Jâmi' li Ahkâm al-Qur'ân, (Kairo: Dâr asy-Sya'b, 1372 H.), vol.V, hal. 168 ditaati dalam hal-hal yang memang diperintahkan Allah. Ketaatan seorang istri kepada suaminya dibuktikan, misalnya, dengan berperilaku baik terhadap keluarga suaminya serta menjaga dan memelihara harta suaminya. Ini karena Allah telah memberikan kelebihan atas suami dari sisi keharusannya memberi nafkah dan berusaha. ${ }^{34}$

Muhammad Abduh membagi kelebihan laki-laki atas perempuan menjadi dua, yaitu fithri dan kasbi. Kelebihan fithri dapat dilihat dalam penciptaan kaum Adam ini yang diciptakan lebih kuat, lebih indah, dan lebih sempurna. Kesempurnaan ini diikuti oleh kesempurnaan akal. Dengan kesempurnaan akal dan fisik ini membuat laki-laki mampu untuk mencari nafkah, berkarya, dan bertindak dalam segala hal. Kelebihan kasbi yang dimaksud adalah kemampuan mencari nafkah bagi lakilaki. Oleh karena itu, laki-laki diberi kewajiban memberi nafkah kepada isterinya. ${ }^{35}$

Secara garis besar memang demikian, walaupun dalam kenyataannya banyak isteri lebih pintar dan lebih berhasil dalam hal ekonomi daripada suami mereka. Contoh yang paling sederhana adalah keluarga Nabi Saw. sendiri yang pada saat menikah dengan Siti Khadijah, beliau tidak begitu kaya. Sebaliknya, Siti Khadijah dikenal sebagai saudagar yang kaya raya. Namun, hal ini tidak menjadikan Siti Khadijah sebagai pemimpin dalam keluarga.

${ }^{34}$ Muhammad ibn 'Ali ibn Muhammad asySyaukâni, Fath al-Qadîr bain Fanni ar-Riwâyah wa ad-Dirâyah min 'Ilm at-Tafsîr, (Beirût: Dâr alFikr, t.t.), vol. I, hal. 462.

${ }^{35}$ Yunahar Ilyas, Konstruksi Pemikiran Gender Dalam Pemikiran Mufassir, (Jakarta: Program Peningkatan Kualitas Pelayanan Publik, Ditjen Bimas Islam dan Penyelenggaraan Haji, 2005), hal. 181 
Keberadaan huruf 'athaf yang menyambungkan dua proposisi tersebut dan adanya huruf yang mengawali kedua proposisi itu menunjukkan bahwa kedua proposisi tersebut memiliki makna yang independen, yang terlepas dari yang lainnya. Dengan kata lain, bahwa proposisi yang pertama bukan proposisi yang kedua,begitu juga sebaliknya. Dengan demikian, alas an $a r-$ rijal dijadikan pemimpin atas an-nisa' didasarkan pada dua sebab, yaitu keutamaan (afdhaliah) yang Allah berikan kepada ar-rijal dan nafkah yang mereka berikan kepada an-nisa'.

\section{Pandangan Ulama tentang kedudukan laki-laki (suami) dan perempuan (isteri)}

Sebagaimana yang sudah dikemukakan di atas, Fakhr ar-Razi ${ }^{36}$ menyatakan bahwa kelebihan kaum pria atas wanita itu terdapat pada banyak aspek. Di antaranya adalah sifat hakiki dan sebagiannya terkait dengan hukumhukum syariat. Sifat hakiki dikembalikan pada dua hal, yakni ilmu dan qudrah (kemampuan). Dua hal inilah yang menghasilkan kelebihan kaum pria atas wanita dalam hal akal, tekad, dan kekuatan; dalam kemampuan menulis, berkuda (berkendaraan), melempar. Dari kalangan mereka pula diutusnya para nabi dan banyaknya para ulama. Imâmah (baik khalifah maupun jabatan penguasa di bawahnya), jihad, azan, khutbah, itikaf, kesaksian dalam masalah hudûd dan qishâs, kelebihan dalam pembagian waris, kewajiban membayar diyat dalam pembunuhan atau kesalahan dan dalam hal sumpah juga ada pada mereka. Kewenangan dalam pernikahan, talak, rujuk, dan berpoligami, penisbatan garis nasab juga ada pada mereka. Semua itu

${ }^{36}$ Fakhr al-Dîn al-Râzi, al-Tafsîr al-Kabîr, (Beirût: Dâr al-Fikr, t.th), hal. 91. menunjukkan adanya kelebihan kaum pria atas kaum wanita.

Kedua, adanya kelebihan dalam hal taklif syariat. Frasa wa bimâ anfaqû min amwâlihim mengandung pengertian bahwa kaum pria memiliki kewajiban untuk memberikan nafkah kepada istri dan kerabat dekat yang menjadi tanggungannya; mereka juga harus membayarkan mahar kepada kaum wanita untuk memuliakan mereka. ${ }^{37}$

Tafsir al-Azhar memahami Qs. alNisâ'/4:34 sebagai argumentasi kepemimpinan laki-laki atas perempuan. Kepemimpinan tersebut erat kaitannya dengan perbandingan 2:1 bagian warisan laki-laki dan perempuan, kewajiban laki-laki membayar mahar, dan perintah kepada suami untuk memperlakukan dengan baik istrinya. Hal ini disebabkan karena lak-laki adalah pemimpin atas perempuan. Kepemimpinan ini disebabkan karena laki-laki memiliki naluri kepemimpinan, sedangkan perempuan memiliki naluri dipimpin. ${ }^{38}$

Tafsir an-Nur menerjemahkan kata qawwâm pada Qs. al-Nisâ' sebagai pengatur ${ }^{39}$ bukan pemimpin seperti pemahaman tafsir pada umumnya. Tugas melindungi bagi laki-laki terhadap perempuan menjadi sebab peperangan hanya diwajibkan bagi lakilaki, tidak untuk perempuan. Hal itu pula yang menyebabkan sehingga lakilaki mendapatkan bagian warisan 2 kali dibanding perempuan. Khusus dalam rumah tangga, laki-lakilah yang menjadi pemimpin ${ }^{40}$. Seperti Tafsir an-Nur, Tafsir al-Furqân juga menerjemahkan kata qawwâm sebagai pengatur. Alasan

${ }^{37}$ Wahbah Zuhaili, al-Fiqh al-Islami wa Adillatuh, hal. 55.

${ }^{38}$ Hamka, Tafsir al-Azhar, (Jakarta: Pustaka Panjimas, 1982 ), vol. V, hal. 46-47

${ }^{39}$ Hasbi Ash-Shiddiqy, Tafsir al-Qur'an alMajid al-Nur, (Semarang: Putra Rizki, 1995), vol. I, hal. 815

${ }^{40}$ Hasbi Ash-Shiddiqy, Tafsir al-Majid alNur, hal. 816 
kepemimpinan laki-laki atas perempuan menurut tafsir ini adalah karena kelebihan laki-laki dan kewajibannya menafkahi istrinya. Kelebihan yang dimaksud adalah kelebihan kekuatan, keberanian, keteguhan hati, dan ketepatan. ${ }^{41}$

Di luar dari dua hal yang dikemukakan di atas, seorang laki-laki adalah setara dan sama dengan seorang wanita dalam hal hak dan kewajibannya. Inilah kebaikan Islam. Allah Swt. berfirman:

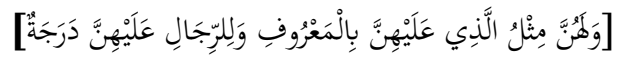

Akan tetapi, para suami mempunyai satu tingkatan kelebihan daripada istrinya. Allah Maha Perkasa lagi Maha Bijaksana. (QS al-Baqarah [2]: 228).

Tanggung jawab suami sebagai kepala rumah tangga, adalah menjaga, membela, bertindak sebagai wali, memberi nafkah dan sebagainya. Lain halnya dengan wanita, ia justru mendapat jaminan keamanan dan nafkah. Itulah sebabnya kaum pria memperoleh warisan dua kali lipat dari bagian wanita. ${ }^{42}$

Demikian juga antara laki-laki dan perempuan, keduanya saling melengkapi dan tidak bertentangan. Laki-laki bertugas untuk mencari nafkah, memelihara istri dan anakanaknya, serta menyediakan kebutuhan hidupnya, sedangkan perempuan bertugas memelihara rumah tangga, hamil, melahirkan mengasuh anak dan menjadi tempat berteduhnya suami guna mendapatkan sakinah dan ketenangan ketika suami datang dari kerja dan kelelahan. Setelah bersusah payah mencari nafkah disambut oleh sang istri dengan senyuman dan kasih sayang yang menghapus semua

41 A. Hassan, Tafsir al-Furqan, (Bangil: Persatuan), hal. 162

42 Huzaimah Tahido Yanggo, Masail Fiqhiyah Kajian Hukum Islam Kontemporer,(Bandung: Angkasa, 2005), hal. 138 kepenatannya kerjanya, dan masingmasing mendapatkan apa yang dibutuhkan apa yang dibutuhkan. ${ }^{43}$

At-Thabari dengan metode tahlili sebagaimana yang diuraikan dahulu, menghubungkan Qs. al-Nisâ'/4: 34 dengan ayat selanjutnya sebagai konsekuensi dari kepemiminan laki-laki atas perempuan bahwa perempuanperempuan sâleh (șâlihât) adalah mereka yang taat (qânitât) melaksanakan kewajiban pada suami, dan menjaga kehormatan dirinya, serta menjaga rumah tangga dan harta benda milik suaminya, tatkala para suami tidak ada di rumah termasuk menjaga rahasia suami

\section{Isteri Taat dan istri Tidak Taat (Nusyuz)}

Selanjutnya Allah Swt menjelaskan keadaan kaum wanita (para istri) dalam kehidupan berumah tangga: adakalanya mereka taat; adakalanya mereka tidak setia (melakukan nusyûz). ${ }^{44}$

$$
\text { Dalam Shafwah at-Tafâsîr, }
$$

dijelaskan bahwa lanjutan ayat:

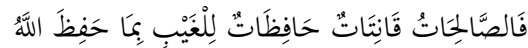

Frasa fa ash-shâlihât qânitât hâfizhâth li al-ghayb bi mâ hafizha Allâh merupakan perincian dari keadaan para wanita yang berada dalam kepemimpinan pria. Allah telah menjelaskan bahwa mereka (para wanita) tersebut terbagi dalam dua keadaan, yakni: (1) kelompok wanita shalihah dan taat; (2) kelompok wanita yang bermaksiat dan membangkang. Wanita shalihah akan senantiasa menaati Allah Swt. dan suaminya selama tidak dalam rangka bermaksiat kepada Allah, senantiasa melaksanakan kewajiban-kewajibannya, menjaga diri mereka dari melakukan perbuatan keji,

\footnotetext{
${ }^{43}$ Huzaimah Tahido Yanggo, Masail Fiqhiyah Kajian Hukum Islam Kontemporer, hal. 139.

44 Wahbah Zuhaili, al-Fiqh al-Islami wa Adillatuh, hal. 55
} 
menjaga kehormatan mereka, menjaga harta suami dan anak-anak mereka, dan menjaga rahasia apa yang terjadi antara mereka berdua (suami-istri) dalam hal apa pun yang layak dijaga kerahasiaannya. ${ }^{45}$

Senada dengan pendapat di atas, Ahsin Sakho Muhammad menerangkan tentang perempuan pertama yang disebutkan dalam ayat ini, bahwasanya al-Qur'an telah mengisyaratkan kriteria isteri shalihah yakni : 1) Qanitat, artinya isteri yang selalu taat, patuh kepada suaminya, yakni dalam keseharian yang tidak sampai kepada penindasan secara fisik, dan kepada kemaksiatan. 2) Hafidzah lil ghaib, artinya isteri yang selalu menjaga dirinya sendiri dan bergaul secara tidak wajar/ melampaui batas dengan laki-laki lain, terutama pada saat suami tidak berada di rumah. Di samping itu, isteri shalihah juga menjaga harta benda suaminya. Hal ini diperkuat dengan hadis Nabi yang berbunyi : "sebaik-baiknya isteri ialah jika memandangnya, engkau senang; jika engkau menyuruhnya dia menurut; dan jika engkau pergi, dia menjaga dirinya dan hartamu". 46

Peran istri yang sholihah ternyata berpengaruh kepada penguatan keluarga itu sendiri sebagai sebuah institusi pendidikan pertama yang melahirkan generasi yang baik. AlQur'an secara lugas membuat tamtsil tentang hal ini. Terdapat kisah dalam alQur'an yang menggambarkan betapa penting peran sang isteri dalam melahirkan generasi yang shaleh. Suami yang taat dan shaleh, tetapi tidak didampingi oleh isteri yang shalihah, ternyata tidak mampu melahirkan generasi yang shaleh. Profil keluarga dua orang nabi yang shaleh yakni Nuh a.s dan Luth a.s yang memiliki isteri hal. 274

${ }^{45}$ Ali ash-Shâbuni, al-Shafwah al-Tafâsir,

\footnotetext{
${ }^{46}$ Ahsin Sakho Muhammad, Keberkahan AlQur'an, hal. 248
}

yang tidak beriman. ${ }^{47}$ Sebaliknya pada isteri yang mukminah yang suaminya kafir, Allah Swt menitipkan seorang bayi yang kelak menjadi nabi (Musa). ${ }^{48}$ Selanjutnya, ada juga suami yang shaleh dan memiliki isteri shalihah, lahirlah anak keturunan yang shaleh pula, sebagaimana kisah nabi Ibrahim a.s ${ }^{49}$

Dengan begitu, dapat disimpulkan bahwa faktor keshalehan kaum perempuan dalam keluarga juga sangatlah penting dalam melahirkan dan membangun generasi yang shaleh dan shalehah.

Selanjutnya, ayat :

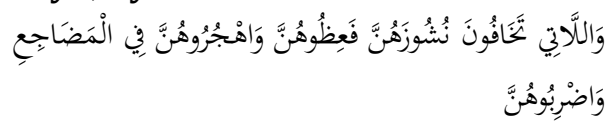

Frasa wallâti takhâfûna

nusyûzahunna adalah menunjuk pada kelompok wanita yang kedua, yakni para wanita yang bermaksiat dan menentang, yakni mereka yang menyombongkan diri dan meninggikan diri dari melakukan ketaatan kepada suami. ${ }^{50}$

Berdasarkan ayat di atas, ketika telah tampak bagi suami tanda-tanda nusyûz ini pada istrinya, suami wajib melakukan beberapa langkah untuk melakukan perbaikan

(mengembalikan istri ke jalan yang benar) dengan menempuh tahapan sebagai berikut:

1. Fa'izhuhunna: memberikan nasihat, petunjuk, dan peringatan yang memberi pengaruh pada jiwa istrinya; dengan mengingatkan istrinya akan ancaman siksa yang diberikan Allah kepadanya karena kemaksiatan yang dilakukannya. ${ }^{51}$ Jika hal itu bermanfaat, itulah yang dikehendaki. Namun apabila

\footnotetext{
${ }^{47}$ Lihat Qs. at-Tahrim [66]: 10

${ }^{48}$ Lihat Qs. at-Tahrim [66]: 11 dan Qs. alQashash [28]: 7-9

${ }^{49}$ Lihat Qs. Ash-Shaffat [37]: 100-102

${ }^{50}$ Ibn Katsîr, Tafsîr al-Qur'ân al-Azhîm, hal. 608.

51 'Ali ash-Shâbuni, al-Shafwah al-Tafâsir, hal. 274
} 
isteri masih juga nusyuz, suami bisa menempuh jalan kedua;

2. Wahjurûhunna fí al-madhâji: memisahkan diri dan berpaling darinya (istri) di pembaringan (pisah ranjang). Ini adalah kinâyah (kiasan) dari meninggalkan jimak (persetubuhan), atau tidak melakukan tidur bersama istri dalam satu tempat tidur yang sama, tidak mengajaknya bicara, dan tidak mendekatinya. Akan tetapi, suami tidak diperkenankan tidak mengajak bicara istri lebih dari 3 hari. Ibn 'Abbas berkata, al-hajru bermakna tidak menjimak istri, tidak tidur bersamanya di pembaringannya, dan berpaling dari punggungnya. ${ }^{52}$ Tindakan ini akan sangat menyakitkan istri; dilakukan untuk membuat seorang istri memikirkan dan merenungkan kembali apa yang telah dilakukannya.

Jika yang demikian telah membuat istri sadar dan menaatinya, suami harus menerimanya dan tidak boleh melakukan langkah yang ketiga. Sebaliknya, jika yang demikian tidak membuat istri sadar juga, suami diperkenankan melakukan langkah yang ketiga.

3. Wadhribûhunna: memberikan pukulan yang tidak menyakitkan dan tidak berbekas; tidak lain tujuannya sema-mata demi kebaikan. ${ }^{53}$ Hal pemukulan secara fisik sebenarnya hanya salah satu cara menghentikan nusyuznya isteri. Masih banyak cara lain selain memukul. Budaya masyarakat, tingkat intelektual, tingkat sosial pada masyakarat bisa menjadi cara tersendiri dalam meredam nusyuz nya seorang isteri.

Selanjutnya, penggalan ayat :

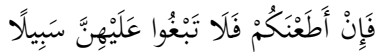

Kalimat $f a$ in atha'nakum falâ tabghû 'alayhinna sabîlâ mengandung

52 'Ali ash-Shâbuni,al-Shafwah al-Tafâsir, hal. 274

${ }^{53}$ Ibn Katsir, Tafsîr al-Qur'ân al-Azhîm, hal. 609. pengertian, bahwa jika istri menaati perintah suami, janganlah suami mencari jalan lain untuk menyakiti istrinya. Artinya, para suami dilarang menzalimi para istri mereka dengan cara lain yang di dalamnya terdapat aktivitas menyakiti dan menyiksa mereka. ${ }^{54}$

Kenyataan yang kadang terjadi di masyarakat banyak suami yang melakukan kekerasan terhadap perempuan bukan karena nusyuz saja, melainkan karena alasan-alasan yang sepele. Hal ini jelas keluar dari batasan yang dibolehkan oleh al-Qur'an.

Pada akhir ayat Allah swt berfirman, إِنَّ النَّ كَانَ عَِليَّا كَبِيرًا. Kalimat Inna Allah kâna 'Aliyyan Kabîrâ menjelaskan sifat Allah yang menyatakan bahwa diri Nya sebagai dzat yang Mahatinggi dan Mahabesar. Ayat ini mengandung pengertian bahwa sesungguhnya Allah lebih tinggi dan lebih besar daripada para suami; Dia adalah pelindung para istri dari siapa pun yang menzalimi dan bertindak melampaui batas terhadap mereka. ${ }^{5}$ Ini adalah peringatan keras bagi para suami agar tidak menzalimi istrinya. Maksudnya adalah agar para suami menerima taubat dari istrinya. Sebab, jika Yang Mahatinggi dan Mahabesar saja senantiasa menerima tobat hamba-Nya yang bermaksiat, maka tentu para suami lebih layak untuk menerima taubat para istri. ${ }^{56}$

\section{Kesimpulan}

Dari uraian di atas, dapatlah ditarik beberapa simpulan :

Pertama, Qs. an-Nisa' [4]: 34 menjelaskan bahwa kedudukan laki-laki lebih tinggi daripada perempuan, karena ayat itu dimaksudkan untuk

\footnotetext{
609.

55 Wahbah Zuhaili, al-Fiqh al-Islami wa Adillatuh, hal. 57.

56 Wahbah Zuhaili, al-Fiqh al-Islami wa Adillatuh, hal. 57
}

${ }^{54}$ Ibn Katsir, Tafsîr al-Qur'ân al-Azhîm, hal. 
mempertegas pembagian tugas antara laki-laki sebagai suami dan perempuan selaku isteri. Tugas suami adalah melindungi, menjaga, bertindak sebagai wali, memberi nafaqah, dan lain-lain. Berbeda dengan kaum perempuan, ia justru mendapat jaminan keamanan dan nafaqah. Itulah sebabnya, laki-laki mendapat warisan 2 kali lebih banyak daripada wanita. Sehingga para perempuan mukminah tidak perlu menggugat bila Islam menyerahkan kepemimpinan rumah tangga di tangan pria, karena Allah Swt. telah menjamin hak-hak wanita dengan sebaik-baiknya, selama rumah tangga tersebut dijalankan sesuai dengan ketentuan Allah Swt.

Kedua, adanya kelebihan yang dimiliki oleh laki-laki (suami), tidak membenarkan mereka melakukan tindakan sewenang-wenang kepada perempuan (isteri). Begitu juga sebaliknya, kaum perempuan tidak dibolehkan meremehkan kelebihan yang dimiliki oleh laki-laki. Sehingga perempuan dalam kapasitasnya sebagai isteri tidak berkeberatan kalau suami menjadi qawwam terhadapnya untuk melindungi, memimpin, menjami, dan menangani urusan-urusannya.

Ketiga, bertalian dengan Qs. anNisa' [4]: 34 ini juga, Allah Swt menggambarkan dua prototype seorang isteri dalam sebuah rumah tangga. Ada yang qanitat dan ada yang nusyuz. Kepada isteri yang berbuat nusyuz, Allah Swt memerintahkan kepada para suami untuk memukul isteri dengan pukulan yang tidak mencederai jika dikhawatirkan nusyuz nya apabila masih belaku nusyuz setelah dinasehati dan dipisahkan dari tempat tidur. Alasan memukul dan tidak mencederai karena darurat sebagai upaya mendidik isteri agar tidak berlaku nusyuz. Dalam hal ini, tindakan memukul merupakan upaya terakhir yang ditempuh oleh suami kepada isterinya. Ketiga tahapan yang ditempuh mulai dari menasihati, memisahkan dari tempat tidur, sampai kepada memukul dilakukan untuk menghindari adanya talak.

Keempat, penegasan Allah Swt kepada para suami untuk tidak berlaku sewenag-wenang kepada isteri. Larangan ini muncul karena ada anggapan bahwa laki-laki (suami) lebih tinggi derajatnya, lebih kuat, lebih berkuasa dari kaum perempuan (isteri). Maka disini, Allah Swt mengingatkan kepada para suami agar kemampuan dan kelebihan itu dimanfaatkan untuk menasihati isterinya, membuat mereka bertakwa kepada Allah Swt.

\section{LITERATUR KEPUSTAKAAN}

A. Hassan, Tafsir al-Furqan, Bangil: Persatuan

Abdul Wahid, Mustafa, Wanita Dalam Pandangan Al-Qur'an, Alih Bahasa oleh: Ali Hasyimi dalam Buku Apa Sebab Al-Qur'an tidak bertentangan dengan Akal, Jakarta: Bulan Bintang, 1989

Abdurrahman, dkk., Al-Qur'an \& Isu-isu Kontemporer, Yogyakarta : eLSAQ Press, 2011

al-Alûsy, Mahmûd, Shihâbuddîn, Rûh alMa'ânî Fi Tafsîr al-Qur'ân al-Azhîm wa Sab'a al-Matsâni, Beirût: Dâr alFikr, vol. I

al-Qurthûbi,Abû Abdillah, Muhammad ibn Ahmad ibn Abi Bakr ibn Farah, al-Jâmi' li Ahkâm al-Qur'ân, Kairo: Dâr asy-Sya'b, 1372 H. vol.V

al-Râzi, Fakhr al-Dîn, al-Tafsîr al-Kabîr, Beirût: Dâr al-Fikr, t.th,

al-Sibâ'î, Musthafâ, Al-Mar'ah baina alFiqh wa al-Qânûn, Cet. III, Kairo: Dâr al-Salâm, 2003

al-Thabarî, Abû Ja'far, Muhammad bin Jarîr bin Yazîd, Tafsîr al-Tabarî, Jilid IV, Kairo: Bûlâq, $1323 \mathrm{H}$

Al-Wâhidi, Asbâb al-Nuzûl al-Qur'ân, CD.Maktabah al-Syamilah 
al-Zuhaili, Wahbah, al-Fiqh al-Islamî wa Adillatuh, Beirût: Dâr al-Fikr, 1989, vol. V.

Ash-Shiddiqy, Hasbi, Tafsir al-Qur'an alMajid al-Nur, Semarang: Putra Rizki, 1995, vol. I

ath-Thabâri, Muhammad ibn Jarîr ibn Yazîd ibn Khâlîd Abû Ja'fâr, Jâmi' al-Bayân 'an Ta'wîl Ay al-Qur'ân, Beirût: Dâr al-Fikr, 1405 H, vol. V

Fayruzzabadi, Muhammad bin Ya'qub, al-Qamus al-Muhith, Kairo: alHaiah al-Mishriyah al 'Ammah li al Kitab, 1980

Hamka, Tafsir al-Azhar, Jakarta: Pustaka Panjimas,1982, vol. V

Hanshary, Hafiz, Ihdad Wanita Karir, dalam Huzaimah T.Yanggo (ed.), Problematika Hukum Islam Kontemporer, Jakarta:Pustaka Firdaus, 2002

Humadi, As'ad Aysar al-Tafasir, CD. Maktabah al-Syamilah

Ibn Katsîr, Abû al-Fidâ', Tafsîr al-Qur'ân al-Azhîm, Beirût: Dâr al-Fikr, 1401, vol. I,

Ibn Manzur, Lisan al-'Arab, Kairo: Dar Kutub al 'Ilmiyyah, 2002

Ibn Qudamah, Al-Mughni Fi Fiqh alImam Ahmad Ibn Hanbal alSyaibani, dalam Kitab al-Nafaqah masalah faidha mana'aha Walam Tajid Ma Ta'khudhuhu. Beirut: Dar al-Fikr, 1405, vol. 9.

Ilyas Yunahar, Konstruksi Pemikiran Gender Dalam Pemikiran Mufassir, Jakarta: 2005

Jalâluddîn as-Suyûthi, Abdur Raḥmân ibn al-Kamâl, Dâr al-Mansyûr fí atTafsîr al-Ma'tsûr, Beirût: Dâr alFikr, t.th, vol. III

Kementerian Agama RI, Tafsir Al-Qur'an Tematik, Jakarta: Lajnah Pentashihan Mushaf Al-Qur'an, 2012

Muhammad, Ahsin Sakho, Keberkahan Al-Qur'an; Memahami Tema-tema Penting Kehidupan dalam Terang
Kitab Suci, Jakarta: PT. Qaf Media Kreativa, 2017

Shâbuni, Ali, al-Shafwah al-Tafâsir, Beirût: Dâr al-Fikr, t.th, vol. II Saeed, Abdullah, Interpreting the Qur'an Towards a Contemporary Approach, New York: Taylor \& Francis Group, 2006

T.Yanggo, Huzaimah, Fiqih Perempuan Kontemporer, Jakarta: al-Mawardi Prima, 2001 Fiqhiyah Kajian Hukum Islam Kontemporer, Bandung: Angkasa, 2005 